\title{
MDRD 6 Variable Formula
}

National Cancer Institute

\section{Source}

National Cancer Institute. MDRD 6 Variable Formula. NCI Thesaurus. Code C161345.

A formula to estimate glomerular filtration rate that takes into account age, sex, race, serum creatinine, serum urea nitrogen, and albumin. eGFR $(\mathrm{mL} / \mathrm{min} / 1.73 \mathrm{~m} 2)=170 \mathrm{x}$ $(\mathrm{SCr} / 88.4)^{\wedge}-0.999 \times$ ag $\mathrm{e}^{\wedge}-0.176 \times(\mathrm{SU} \times 2.78)^{\wedge}-0.170 \times$ albumin^ $0.318 \times(0.762$, if female $)$ x (1.18, if African American). (Levey AS, Greene T, Kusek JW, Beck GJ, MDRD study group. A simplified equation to predict glomerular filtration rate from serum creatinine. J Am Soc Nephrol 2000; 11: A0828.) 